\title{
Person-specific Characteristics of People with Low Back Pain Moderate the Preferred Movement Pattern within Motor Skill Training and Strength and Flexibility Exercise
}

Quenten L. Hooker, $\mathrm{PhD}^{1}$

Linda R. van Dillen, $\mathrm{PhD}^{1,2}$

${ }^{1}$ Program in Physical Therapy, Washington University School of Medicine, St. Louis, Missouri, United States

${ }^{2}$ Department of Orthopaedic Surgery, Washington University School of Medicine, St. Louis, Missouri, United States

Running Title: Individual Characteristics Moderate Movement

Corresponding author:

Linda R. van Dillen

4444 Forest Park Boulevard, Campus Box 8502

Program in Physical Therapy

Washington University in St. Louis, School of Medicine

St. Louis, MO 63108

United States of America

Email: vandillenl@wustl.edu

Funding Source: This project was funded by National Institutes of Health (R01 HD047709). QLH was supported by a training grant from National Institutes of Health (TL1 TR002344).

Acknowledgments: The authors would like to thank Sara Putnam, Sara Francois, Kristen Roles, and Jennifer Jarvis for their assistance with participant recruitment, data collection and data processing. 
medRxiv preprint doi: https://doi.org/10.1101/2022.02.28.22271619; this version posted March 2, 2022. The copyright holder for this preprint (which was not certified by peer review) is the author/funder, who has granted medRxiv a license to display the preprint in perpetuity. All rights reserved. No reuse allowed without permission.

1 Person-specific Characteristics of People with Low Back Pain Moderate the Preferred

$2 \quad$ Movement Pattern within Motor Skill Training and Strength and Flexibility Exercise

3

4

5

6

7

8

9

10

11

12

13

14

15

16

17

18

19 Abstract count: 290

20 Main text count: 3475 
medRxiv preprint doi: https://doi.org/10.1101/2022.02.28.22271619; this version posted March 2, 2022. The copyright holder for this preprint (which was not certified by peer review) is the author/funder, who has granted medRxiv a license to display the preprint in perpetuity.

All rights reserved. No reuse allowed without permission.

$\underline{\text { Abstract }}$

Background: People with chronic low back pain (LBP) display an altered movement pattern where the lumbar spine moves more readily into its available range of motion relative to other joints when performing a movement. Recently a randomized controlled trial was completed to compare the effects of motor skill training (MST) to strength and flexibility exercise (SFE). MST improved the altered pattern to a greater extent than SFE. However, there was substantial variability in the baseline and the change over time in the pattern. Understanding factors that influence this variability may ultimately be used to better target treatment strategies to the person.

Objective: Examine if gender, age, LBP duration, and the movement pattern at baseline moderate the baseline movement pattern and the change over time in the pattern within MST and SFE. Design: Secondary analysis of kinematic data from a single-blind, randomized controlled clinical trial.

Setting: Institutional

Patients: 154 patients with chronic LBP.

Interventions: Motor skill training and strength and flexibility exercise.

Main outcome measures: lumbar contribution (LC) to total movement.

Results: There was not a significant difference in baseline LC between MST and SFE ( $\beta=-2.39$, $\mathrm{Cl}=[-7.74,2.96], \mathrm{p}=0.38)$. SFE did not change LC over time $(\beta=-0.11, \mathrm{Cl}=[-0.47,0.24], \mathrm{p}=0.53)$. However, there was a significant change over time in LC within MST $(\beta=-2.13, C l=[-2.54,-1.48]$, $p<0.001)$. Irrespective of treatment group, there was a trend for gender $(\beta=-5.29, C l=[-10.34$, $0.30], p=0.05)$ and age $(\beta=-0.22, C l=[-0.46,0.00], p=0.05)$ to moderate baseline LC. Age $(\beta=0.01$, $C l=[0.00,0.02], p=0.04)$ and baseline LC $(\beta=-0.07, C l=[-0.10,-0.04], p<0.01)$ were associated with the change over time in LC within MST only. within MST and SFE, as well as the change over time in the pattern within MST. 
medRxiv preprint doi: https://doi.org/10.1101/2022.02.28.22271619; this version posted March 2, 2022. The copyright holder for this preprint (which was not certified by peer review) is the author/funder, who has granted medRxiv a license to display the preprint in perpetuity. All rights reserved. No reuse allowed without permission.

46 Keywords: chronic low back pain, motor skill training, strength and flexibility exercise, movement

47 pattern

48

49

50

51

52

53

54

55

56

57

58

59

60

61

62

63

64

65 
medRxiv preprint doi: https://doi.org/10.1101/2022.02.28.22271619; this version posted March 2, 2022. The copyright holder for this preprint (which was not certified by peer review) is the author/funder, who has granted medRxiv a license to display the preprint in perpetuity.

\section{$\underline{\text { Introduction }}$}

The primary reason people with LBP seek medical treatment is difficulty in performing daily functional activities. ${ }^{1,2}$ Given the importance of function, researchers have investigated aspects of how people with LBP perform functional activities. Numerous differences in movement characteristics have been reported between back healthy controls and people with LBP. ${ }^{3,4}$ However, specific movement characteristics (e.g., movement velocity) often do not explain substantial variance in LBP-related function. ${ }^{5}$ One set of studies in particular has documented that compared to back healthy controls, people with chronic LBP display an altered movement pattern where the lumbar spine moves more readily into its available range of motion compared to other joints (e.g., knee and hip). ${ }^{6,7}$ Previously, the altered pattern has been indexed as the magnitude of early (first $50 \%$ of descent) lumbar movement during an activity. This pattern is of particular clinical relevance because across multiple studies the magnitude of altered movement is associated with LBP symptoms and functional limitations. ${ }^{6,8,9}$ Therefore, the altered pattern is prevalent in people with chronic LBP and relevant to the clinical presentation.

Exercise-based treatment can improve the altered movement pattern during functional activities in people with chronic LBP. ${ }^{10}$ For example, motor skill training (MST) uses personspecific, challenging practice to drive learning of new motor skills. ${ }^{11-13}$ The primary goal of MST during LBP-limited functional activities is to replace the long-standing, pain-provoking, altered movement pattern with a pain-free pattern. ${ }^{10,12,13}$ One study documented that one session of MST immediately improved the altered movement pattern during a functional activity test of picking up an object (PUO), and the improved pattern was associated with an immediate reduction in LBP symptoms. ${ }^{10}$ More recently, the short- and long-term effects of MST were compared to strength and flexibility exercise (SFE). After 6 weeks of MST, on average, people with chronic LBP improved their movement pattern. ${ }^{14}$ Specifically, there was a significant decrease in early lumbar excursion and increase in early knee and hip excursion during the PUO test. ${ }^{14}$ The improved 
medRxiv preprint doi: https://doi.org/10.1101/2022.02.28.22271619; this version posted March 2, 2022. The copyright holder for this preprint (which was not certified by peer review) is the author/funder, who has granted medRxiv a license to display the preprint in perpetuity.

All rights reserved. No reuse allowed without permission.

91 pattern was maintained 6 months after treatment. ${ }^{14}$ SFE, however, did not change the movement

92 pattern across the study duration. ${ }^{14}$ Furthermore, the improved movement pattern in MST

93 corresponded with greater improvements in pain and function compared to SFE. ${ }^{13}$ Although on

94 average MST improved the altered movement pattern and SFE did not, there was substantial

95 variability in the baseline and the change over time in the pattern within both treatment groups.

96 This variability suggests that some people with LBP improved the pattern to a greater extent than

97 others. In order to better refine MST and SFE for people with LBP, it is critical to understand the

98 variability from one person to another in the (1) altered movement pattern at baseline and (2) change over time in the pattern.

One reason for the substantial variability in the pattern at baseline and change over time

on prior reports, there are many person-specific characteristics that have the potential to influence the pattern. First, prior studies suggest there are differences in movement patterns between men and women. ${ }^{15-20}$ Thus, there may be characteristics specific to gender that influence the altered movement pattern at baseline and the change over time in the pattern. ${ }^{21,22}$ Second, previous work suggests a person's age is associated with movement characteristics, such as spinal range of

107 motion, ${ }^{23,24}$ as well as the clinical course of LBP. ${ }^{25,26}$ Therefore, age could influence the baseline 108 pattern, as well as the effectiveness of the exercise-based intervention. Third, duration of LBP is 109 frequently reported as a prognostic factor of LBP recovery. ${ }^{26}$ Given the previously reported 110 relationship of the altered movement pattern and clinical outcomes, ${ }^{6,8,9}$ duration of LBP may 111 explain the baseline and change over time in the pattern. Lastly, in prior work the magnitude of 112 the altered movement pattern at baseline was associated with the amount of improvement after 113 one session of MST. ${ }^{10}$ Additional research is needed to understand if a relationship also exists 114 between the magnitude of baseline altered movement pattern and the change over time. 115 Understanding the relationship of these person-specific characteristics to the baseline pattern and 
medRxiv preprint doi: https://doi.org/10.1101/2022.02.28.22271619; this version posted March 2, 2022. The copyright holder for this preprint (which was not certified by peer review) is the author/funder, who has granted medRxiv a license to display the preprint in perpetuity.

All rights reserved. No reuse allowed without permission.

change over time pattern may ultimately be used to better target treatment strategies to the person and improve the effectiveness and efficiency of care.

The purpose of this study was to examine if person-specific characteristics of gender, age, duration of LBP, and baseline altered movement pattern are associated with both the baseline and the change over time in the altered movement pattern within the MST and SFE treatment groups. We hypothesized that the above-mentioned person-specific characteristics would moderate the baseline pattern and change over time in the pattern.

\section{Methods}

Participants

This is a planned secondary analysis of kinematic data from a single-blind, prospective, randomized controlled clinical trial (Clinicaltrials.gov: NCT02027623). 154 people with chronic ${ }^{27,28}$ non-specific ${ }^{29}$ LBP were recruited by way of word of mouth, ads through local media, clinics in the region and flyers placed in the community. Inclusion criteria for the study included 1) 18-60 years of age, 2) chronic $^{27,28}$ LBP for at least 1 year, 3) experienced LBP but not in an acute flare-up ${ }^{30}$, 4) modified Oswestry Disability Questionnaire (MODQ) ${ }^{31}$ score of $\geq 20 \%, 5$ ) difficulty performing at least 3 activities, 6) ability to stand and walk without assistance and 7) ability to understand and sign a consent form. Participants were excluded if they had a BMI $>30$, any structural spinal deformity, spinal tumor or infection and symptomatic disc herniation by clinical examination. Additional exclusion criteria can be found on Clinical.Trials.gov (ID \#: NCT02027623). This study was approved by the Institutional Review Board and all participants provided written informed consent before enrolling in the clinical trial (IRB ID\#: 201205051).

\section{*Insert Table 1}

Data collection 
medRxiv preprint doi: https://doi.org/10.1101/2022.02.28.22271619; this version posted March 2, 2022. The copyright holder for this preprint (which was not certified by peer review) is the author/funder, who has granted medRxiv a license to display the preprint in perpetuity.

All rights reserved. No reuse allowed without permission.

Participants completed laboratory sessions for movement analysis at baseline,

immediately post-treatment and 6 months after treatment. For the secondary analysis we used a subset of self-report measures that were completed during the clinical trial to describe the study sample. These included 1) demographic and LBP history questionnaire, 2) MODQ, 3) Numeric Rating Scale (NRS) ${ }^{32}$ for average and worst LBP symptoms (previous 7 days), 4) Fear-Avoidance Beliefs Questionnaire (FABQ) $)^{33,34}$ and 5) Short Form Health Survey (SF-36). ${ }^{35}$ Prior to treatment, a standardized clinical examination was performed by a trained physical therapist to classify the person's LBP. ${ }^{36-39}$ LBP classification was used to guide the person-specific treatment within MST. Classification was based on the person's altered movement and alignment patterns of the lumbar region and LBP symptom reports during clinical tests. ${ }^{40,41}$

Reflective markers were placed bilaterally on the trunk, pelvis, and lower extremity, according to previously published proceedures. ${ }^{6,7}$ Participants were instructed to perform three trials of a standardized functional activity test of picking up an object (PUO). Measures were obtained at baseline, post-treatment and 6-months post-treatment. For the PUO test, participants stood with their feet pelvis width apart and were asked to pick up the light weight container with both hands and return to the starting position. The light weight container was placed at a height equal to the fibular head and a distance of $50 \%$ of trunk length. No instruction was given as to how to complete the PUO test. Further details of the PUO test can be found in Marich et al. ${ }^{7,10}$ Marker co-ordinate data were collected for both a standing calibration trial and the PUO trials using a three-dimensional motion capture system (Vicon Motion Systems, LTD, Denver, CO) with a sampling rate of $120 \mathrm{~Hz}$. Marker trajectory data were tracked using Nexus 2.7 .1 (Vicon Motion Systems, LTD, Denver, CO). Data were further processed using custom algorithms written in Visual 3D (C-Motion Inc., Germantown, MD) and MATLAB (MathWorks Inc., Natick, MA). Marker position data were filtered using a $4^{\text {th }}$ order low-pass Butterworth filter with a cut-off frequency of $3 \mathrm{~Hz}$. The cut-off frequency was based on residual analysis ${ }^{42}$ using similar functional activity movement tests. ${ }^{6,7}$ Markers (e.g., lumbar: T12, L3 and S1) were used to create segment 
medRxiv preprint doi: https://doi.org/10.1101/2022.02.28.22271619; this version posted March 2, 2022. The copyright holder for this preprint (which was not certified by peer review) is the author/funder, who has granted medRxiv a license to display the preprint in perpetuity.

All rights reserved. No reuse allowed without permission.

specific coordinate systems to track movement across time. Then joint angles were calculated as the distal coordinate system relative to the proximal coordinate system (e.g., hip $=$ femur segment relative to pelvis segment). ${ }^{6,7}$ The primary variable of interest for this study was the magnitude of altered movement pattern. We used lumbar contribution (LC), which was a ratio of early lumbar movement relative to early total movement, to index the magnitude of the altered movement pattern. Early total movement was defined as the summation of early movement of the lumbar spine, hip, and knee joint. Early was defined as the $1^{\text {st }} 50 \%$ of movement time for the descent phase of the PUO task. ${ }^{6,7,10}$ The lumbar contribution index was calculated using the following equation:LC $=\frac{\text { Early Lumbar }}{\text { Early Total }}=\frac{\text { Early Lumbar }}{\text { Early Lumbar+Early Hip+Early Knee }}$. For example, a LC of 0.50 would be interpreted as the lumbar spine contributing $50 \%$ of the total movement during the early phase of the PUO test. Therefore, a greater LC represents a greater magnitude of altered movement pattern.

Participants were randomized to either MST or SFE. All participants received 6, 1-hour treatment sessions, scheduled once/week for 6 weeks. Complete details of the treatment conditions can be found on Clinicaltrials.gov (NCT02027623). SFE focused on increasing the strength of all of the trunk muscles and improving all planes of trunk and lower limb flexibility based on ACSM guidelines. ${ }^{43}$ MST involved challenging, person-specific practice to improve pain provoking, altered movement and alignment patterns during the performance of functional activities. The primary objectives of treatment were to train the participant to 1) decrease the amount of early lumbar spine movement related to the person's LBP classification (e.g., flexion), 2) increase the contribution of movement of other joints (e.g., knees and hips) and 3) avoid end range movements or alignments of the lumbar spine in the specific direction related to the participant's LBP classification. Physical therapists minimized the extrinsic feedback given to participants during practice. Training focused on problem solving by the participant to learn to 
medRxiv preprint doi: https://doi.org/10.1101/2022.02.28.22271619; this version posted March 2, 2022. The copyright holder for this preprint (which was not certified by peer review) is the author/funder, who has granted medRxiv a license to display the preprint in perpetuity.

All rights reserved. No reuse allowed without permission. characteristic and 2) interactions among the three domains of variables.

Data analysis treatment groups at baseline.

perform the activities without increasing LBP symptoms. Both treatment conditions were progressed based on the participant's ability to perform the exercise or activity independently. ${ }^{44}$

All analyses were performed using R v3.5.3. ${ }^{45-47}$ Descriptive statistics were calculated for participant demographics and self-report measures. Two-sample t-tests and chi-square tests of independence were used to test for significant differences $(p<0.05)$ in characteristics between

We used hierarchical linear modeling (HLM) to examine the moderating effects of gender, age, LBP duration, and baseline LC on the baseline LC and change over time in LC. HLM is a regression-based approach that represents trajectories of participants over time by modeling responses at multiple levels of measurement. ${ }^{48}$ HLM is a recommended strategy for longitudinal data that 1) differ in measurement intervals, 2) are nested in separate levels of measurement (e.g., time within each participant) and 3) contain outcomes of either continuous or categorical data. $^{48}$ Given our study design and variables fit these criteria HLM is an appropriate analytic technique. Initially, the LC outcomes were modeled over time at level 1 (i.e., baseline, posttreatment, and 6 month follow up). The level 1 analysis estimated each person-specific intercept, linear time component, and non-linear time component (i.e., quadratic). Moderators of the personspecific LC outcome trajectories were modeled at level 2. The moderators were treatment group (TxGroup), gender, age, duration of LBP, and baseline LC. Also at level 2, we included the variability in coefficients from level 1 , as a function of TxGroup, person-specific characteristics, and the interactions of TxGroup X each characteristic. Specific contrasts of the level 2 effects were calculated to test for the 1) main effect of time, TxGroup, and each person-specific

212 Results 
medRxiv preprint doi: https://doi.org/10.1101/2022.02.28.22271619; this version posted March 2, 2022. The copyright holder for this preprint (which was not certified by peer review) is the author/funder, who has granted medRxiv a license to display the preprint in perpetuity.

Study sample

The study sample included 154 participants. Twenty-one (13.6\%) participants withdrew over the study duration. Participant characteristics, grouped by treatment group, are summarized in Table 1. There were no significant differences between MST and SFE for any participant characteristic at baseline (Table 1).

Treatment Effects

There was not a significant difference in baseline LC between MST and SFE $(\beta=-2.39$, SE $=2.73, p=0.38)$. Within SFE there was not a significant linear slope $(\beta=-0.11, S E=.18, p=$ 0.53) or quadratic component $(\beta=0.001$, SE $=0.005, p=0.86)$. The specific treatment group comparisons in the change over time in LC indicate that there was a significant difference in the

223 linear slope and curvilinearity ( $p$ s $<0.05$, Table 2). Within MST there was a significant overall linear slope $(\beta=-2.13, \mathrm{SE}=0.20, p<0.01)$ and quadratic component $(\beta=0.05$, SE $=.01, p<$ 0.01). The effects within MST were a result of a decrease in LC during the treatment phase, plateauing after the completion of treatment, and regressing at 6 months $(\beta=1.04, \mathrm{SE}=.18, p<$ 0.01).

\section{Person-Specific Effects}

Gender: Irrespective of treatment group there was a trend for a significant difference in baseline LC between men and women $(\beta=-5.29, \mathrm{SE}=2.69, \mathrm{p}=0.05)$. Specifically, men had a greater LC than women across all time points in the study (Figure 1). There was not a significant difference in the linear change over time in LC between men and women within SFE or MST 233 (Table 2). Age: Irrespective of treatment group there was a trend for a relationship of age and LC at baseline $(\beta=-0.22$, SE $=0.12 p=0.06)$. This corresponds to a 0.22 unit decrease in $L C$ for every additional 1 year of age; older people tend to have a smaller baseline LC. Within SFE there 
medRxiv preprint doi: https://doi.org/10.1101/2022.02.28.22271619; this version posted March 2, 2022. The copyright holder for this preprint (which was not certified by peer review) is the author/funder, who has granted medRxiv a license to display the preprint in perpetuity.

All rights reserved. No reuse allowed without permission.

MST, age moderated the linear change over time $(\beta=0.01, \mathrm{SE}=.004, p<0.01)$. Specifically older participants have a flatter (less negative) slope than younger participants (Figure 2). $\underline{L B P}$ Duration: Across MST and SFE there was not a significant relationship of duration of LBP and baseline LC $(\beta=-0.19$, SE $=.16, p=0.24)$ or the linear change over time in LC (Table 2). Baseline LC: Within SFE there was no significant relationship of baseline LC and the linear change over time in LC (Table 2). However, in MST there was a significant relationship of baseline LC and the linear change over time in LC $(\beta=-.07, \mathrm{SE}=.01, p<0.01)$. People within MST with a greater baseline LC had a more negative slope than those with less baseline LC (Figure 1).

*Insert Table 2

*Insert Figure 1

Discussion

The purpose of this study was to examine if the person-specific characteristics of gender, age, duration of LBP, and magnitude of baseline LC were associated with the baseline pattern and change over time in the pattern within MST and SFE. Our hypothesis that person-specific characteristics would moderate the altered movement pattern was partially supported. First, there was a trend for differences between men and women in baseline LC, but gender did not moderate the change over time in LC within either treatment group. Second, there was a trend for a relationship of age and the baseline LC. However, age only significantly moderated the change over time in LC within MST. Third, duration of LBP was not associated with the baseline or change over time in the altered movement pattern. Finally, baseline LC was associated with the change over time in LC only within MST. Therefore, these data support that person-specific characteristics are relevant to the magnitude of the altered movement pattern at baseline and the change over time in the pattern in MST. 
medRxiv preprint doi: https://doi.org/10.1101/2022.02.28.22271619; this version posted March 2, 2022. The copyright holder for this preprint (which was not certified by peer review) is the author/funder, who has granted medRxiv a license to display the preprint in perpetuity.

All rights reserved. No reuse allowed without permission.

Irrespective of treatment group, there was a trend for a significant difference in baseline LC between men and women. Specifically, men had 5.3\% greater LC than women. The modeled differences in LC between men and women were observed consistently across the study duration ( $p s=0.03$ to 0.05 ); men moved more in their lumbar spine early relative to other joints compared to women. There also was no difference in the trajectory of change over time in LC between men and women within MST and SFE. Similar to prior research, these data suggest men and women perform functional activity tests differently. ${ }^{19,20,22}$ However, if given the appropriate training to directly improve the altered movement pattern, men and women can both improve to a similar extent. Therefore, a clinician may expect men and women to perform a functional activity test differently, but both genders have a similar capacity to improve the altered movement pattern. ${ }^{22}$

There was a trend for age and baseline lumbar contribution to be associated. Specifically,

271 for people who are 1 standard deviation older (mean $+1 S D=54.3$ years) than the mean (42.6

272 years) there is a $2.6 \%$ reduction in lumbar contribution; the opposite effect holds for people who

273 are younger than the sample mean. Interestingly, age also moderated the change over time in

274 lumbar contribution within MST (Figure 1B). For example, older people had a smaller change over

275 time in LC, compared to younger people. Older people also did not retain the improved pattern 276 as well as younger people. Although these relationships are statistically significant, these findings 277 should be interpreted with caution. Even across multiple decades of age, people within MST 278 improve the magnitude of altered movement pattern during the functional activity test of PUO. 279 Therefore, age has a relatively small effect on baseline and the change over time in LC, and MST 280 improved the altered movement pattern in both younger and older people. We found that the number of years someone has LBP is not associated with the magnitude

282 of altered movement pattern at baseline or the change in the pattern over time. Previously, a moderate positive relationship $(r=0.39)$ was reported between LBP duration and change in the 284 altered movement pattern after one session of MST. ${ }^{10}$ Specifically, the prior study reported that 
medRxiv preprint doi: https://doi.org/10.1101/2022.02.28.22271619; this version posted March 2, 2022. The copyright holder for this preprint (which was not certified by peer review) is the author/funder, who has granted medRxiv a license to display the preprint in perpetuity.

All rights reserved. No reuse allowed without permission.

the longer the person had LBP the greater improvement in the altered pattern after one session of MST. ${ }^{10}$ One reason for the discrepancy from the current study is that prior work examined the change in the pattern after 1, 20 minute session of MST, as opposed to 6, 1-hour treatment sessions that were once/week for 6 weeks. ${ }^{10}$ Thus, the moderate relationship of duration of LBP and change in the altered movement pattern after one session of MST is not observed over the short-term (i.e., 6 weeks) or long-term (i.e., 6 months). The lack of association of LBP duration and change in the pattern over time is of particular importance for those within the MST group, because these data highlight that repeated sessions of MST improved a long-standing, painprovoking, altered movement pattern, irrespective of how long the person had LBP.

Baseline LC moderated the change over time in LC within MST. Specifically, people with greater LC in MST initially had a greater improvement (more negative slope) compared to people with less LC (Figure 2D). These data mirror the relationship of baseline early lumbar excursion and the change in early lumbar excursion after one 20 -minute session of motor skill training. ${ }^{29}$ The people with the greatest magnitude of altered movement pattern at baseline change the most following MST because they have the greatest potential to change. Furthermore, comparing the trajectories of the change over time for those with greater LC in SFE and MST, people with greater baseline lumbar contribution have a vastly different trajectory. Those with a higher level of altered movement pattern in SFE do not improve the altered pattern; whereas those in MST have a rapid improvement. These data further indicate that if a goal of treatment for people with chronic LBP is to improve the altered movement pattern associated with function, MST is superior to SFE.

Although our findings support that there are person-specific factors that may help refine treatment, this study has limitations. First, these findings are relevant to the altered movement pattern during one functional activity test. Additional research is necessary to determine whether these effects are similar in other functional activities that are limited in people with LBP. Second, we excluded people with a BMI > 30 and specific LBP conditions (e.g., disc herniation). Therefore, 
medRxiv preprint doi: https://doi.org/10.1101/2022.02.28.22271619; this version posted March 2, 2022. The copyright holder for this preprint (which was not certified by peer review) is the author/funder, who has granted medRxiv a license to display the preprint in perpetuity.

All rights reserved. No reuse allowed without permission.

310 these data may not be generalizable to all people with chronic LBP. In addition, other person-

311 specific characteristics not tested in this study should be examined.

312 Conclusion

313 Our findings suggest that person-specific characteristics such as gender, age and 314 baseline lumbar contribution moderate the baseline and change over time in the magnitude of the

315 altered movement pattern. Alternatively, duration of LBP is not associated with the pattern at 316 baseline or the change over time. These person-specific characteristics, in part, explain the 317 variable movement pattern trajectories over time. These findings are of specific importance 318 because understanding factors that influence person-level variability can ultimately be used to 319 better target treatment strategies to the person. Lastly, our findings are clinically relevant because 320 even accounting for the person-specific variability in the movement pattern, MST is superior to 321 SFE in improving the altered movement pattern in people with chronic LBP. 
medRxiv preprint doi: https://doi.org/10.1101/2022.02.28.22271619; this version posted March 2, 2022. The copyright holder for this preprint (which was not certified by peer review) is the author/funder, who has granted medRxiv a license to display the preprint in perpetuity.

All rights reserved. No reuse allowed without permission.

\section{References}

1. Ferreira ML, Machado G, Latimer J, Maher C, Ferreira PH, Smeets RJ. Factors defining care-seeking in low back pain -a meta-analysis of population based surveys. Eur J Pain. 2010;14(7):747.

2. McPhillips-Tangum CA, Cherkin DC, Rhodes LA, Markham C. Reasons for repeated medical visits among patients with chronic back pain. Journal of General Internal Medicine. 1998;13(5):289-295.

3. Laird RA, Gilbert J, Kent P, Keating JL. Comparing lumbo-pelvic kinematics in people with and without back pain: a systematic review and meta-analysis. BMC Musculoskelet Disord. 2014;15:229.

4. $\quad$ Laird RA, Keating JL, Ussing K, Li P, Kent P. Does movement matter in people with back pain? Investigating 'atypical'lumbo-pelvic kinematics in people with and without back pain using wireless movement sensors. BMC Musculoskelet Disord. 2019;20(1):28.

5. Wernli K, Tan J-S, O'Sullivan P, Smith A, Campbell A, Kent P. Does movement change when low back pain changes? A systematic review. J Orthop Sports Phys Ther. 2020(0):1-48.

6. Marich AV, Hwang CT, Salsich GB, Lang CE, Van Dillen LR. Consistency of a lumbar movement pattern across functional activities in people with low back pain. Clin Biomech (Bristol, Avon). 2017;44:45-51.

7. Marich AV HC, Sorensen CJ, van Dillen LR. Examination of the lumbar movement pattern during a clinical test and a functional activity test in people with and without low back pain. Phys Med Rehabil. 2019;12:140-146.

8. Scholtes SA, Norton BJ, Lang CE, Van Dillen LR. The effect of within-session instruction on lumbopelvic motion during a lower limb movement in people with and people without low back pain. Man Ther. 2010;15(5):496-501.

9. Van Dillen LR, Sahrmann SA, Norton BJ, Caldwell CA, McDonnell MK, Bloom N. The effect of modifying patient-preferred spinal movement and alignment during symptom testing in patients with low back pain: a preliminary report. Arch Phys Med Rehabil. 2003;84(3):313-322.

10. Marich AV, Lanier VM, Salsich GB, Lang CE, Van Dillen LR. Immediate effects of a single session of motor skill training on the lumbar movement pattern during a functional activity in people with low back pain: a repeated-measures study. Phys Ther. 2018;98(7):605-615.

11. Boudreau SA, Farina D, Falla D. The role of motor learning and neuroplasticity in designing rehabilitation approaches for musculoskeletal pain disorders. Man Ther. 2010;15(5):410-414.

12. Lanier VM, Lang CE, Van Dillen LR. Motor skill training in musculoskeletal pain: a case report in chronic low back pain. Disabil Rehabil. 2018:1-9.

13. van Dillen LR, Lanier VM, Steger-May K, et al. Effect of Motor Skill Training in Functional Activities vs Strength and Flexibility Exercise on Function in People With Chronic Low Back Pain: A Randomized Clinical Trial. JAMA Neurol. 2021;78(4):385-395.

14. Hooker QL, Lanier VM, Roles K, van Dillen LR. Motor skill training versus strength and flexibility exercise in people with chronic low back pain: Preplanned analysis of effects on kinematics during a functional activity. Clin Biomech (Bristol, Avon). 2022;92:105570.

15. Gombatto SP, Collins DR, Sahrmann SA, Engsberg JR, Van Dillen LR. Gender differences in pattern of hip and lumbopelvic rotation in people with low back pain. Clin Biomech (Bristol, Avon). 2006;21(3):263-271.

16. Hoffman SL, Johnson MB, Zou D, Van Dillen LR. Differences in end-range lumbar flexion during slumped sitting and forward bending between low back pain subgroups and genders. Man Ther. 2012;17(2):157-163. 
medRxiv preprint doi: https://doi.org/10.1101/2022.02.28.22271619; this version posted March 2, 2022. The copyright holder for this preprint (which was not certified by peer review) is the author/funder, who has granted medRxiv a license to display the preprint in perpetuity.

All rights reserved. No reuse allowed without permission.

416

417

418

419

420

421

422

423

424

425

426

427

428

429

430

17. Norton BJ, Van Dillen LR, Sahrmann SA. Gender-related differences in hip and back motion during rising from a forward bent position. J Orthop Sports Phys Ther. 2005;35(1):48.

18. Scholtes SA, Van Dillen LR. Gender-related differences in prevalence of lumbopelvic region movement impairments in people with low back pain. J Orthop Sports Phys Ther. 2007;37(12):744-753.

19. Thomas JS, Corcos DM, Hasan Z. The influence of gender on spine, hip, knee, and ankle motions during a reaching task. Journal of Motor Behavior. 1998;30(2):98-103.

20. Norton BJ, Sahrmann SA, Van Dillen LR. Differences in measurements of lumbar curvature related to gender and low back pain. J Orthop Sports Phys Ther. 2004;34(9):524-534.

21. Carmona M, Tzioupis C, LiArno S, Faizan A, Argenson J-N, Ollivier M. Upper femur anatomy depends on age and gender: a three-dimensional computed tomography comparative bone morphometric analysis of 628 healthy patients' hips. J Arthroplasty. 2019;34(10):2487-2493.

22. Hoffman SL, Johnson MB, Zou D, Van Dillen LR. Gender differences in modifying lumbopelvic motion during hip medial rotation in people with low back pain. Rehabil Res Pract. 2012.

23. Shojaei I, Salt EG, Hooker Q, Van Dillen LR, Bazrgari B. Comparison of lumbo-pelvic kinematics during trunk forward bending and backward return between patients with acute low back pain and asymptomatic controls. Clin Biomech (Bristol, Avon). 2017;41:66-71.

24. Arampatzis A, Frank J, Laube G, Mersmann F. Trunk muscle strength and lumbo-pelvic kinematics in adolescent athletes: Effects of age and sex. Scand J Med Sci Sports. 2019;29(11):1691-1698.

25. Chou $\mathrm{R}$, Shekelle $\mathrm{P}$. Will this patient develop persistent disabling low back pain? JAMA. 2010;303(13):1295-1302.

26. Kent PM, Keating JL. Can we predict poor recovery from recent-onset nonspecific low back pain? A systematic review. Man Ther. 2008;13(1):12-28.

27. Frymoyer JW. Back pain and sciatica. N Engl J Med. 1988;318(5):291-300.

28. Stanton TR, Latimer J, Maher CG, Hancock MJ. A modified Delphi approach to standardize low back pain recurrence terminology. Eur Spine J. 2011;20(5):744-752.

29. Nordin M, Weiser S, van Doorn JW, Hiebert R. Nonspecific low back pain. In: Rom WN, ed. Environmental and Occupational Medicine. 3rd ed. Philadelphia, PA: LippincottRaven Publishers; 1998:947-956.

30. Von Korff M. Studying the natural history of back pain. Spine (Phila Pa 1976). 1994;19(18 Suppl):2041S-2046S.

31. Fritz JM, Irrgang JJ. A comparison of a modified Oswestry Low Back Pain Disability Questionnaire and the Quebec Back Pain Disability Scale. Phys Ther. 2001;81(2):776788.

32. Jensen MP, Turner JA, Romano JM. What is the maximum number of levels needed in pain intensity measurement? Pain. 1994;58(3):387-392.

33. Leeuw M, Goossens ME, Linton SJ, Crombez G, Boersma K, Vlaeyen JW. The fearavoidance model of musculoskeletal pain: current state of scientific evidence. J Behav Med. 2007;30(1):77-94.

34. Waddell G, Newton M, Henderson I, Somerville D, Main CJ. A Fear-Avoidance Beliefs Questionnaire (FABQ) and the role of fear-avoidance beliefs in chronic low back pain and disability. Pain. 1993;52(2):157-168.

35. Jenkinson C, Coulter A, Wright L. Short form 36 (SF36) health survey questionnaire: normative data for adults of working age. BMJ. 1993;306(6890):1437-1440. 
medRxiv preprint doi: https://doi.org/10.1101/2022.02.28.22271619; this version posted March 2, 2022. The copyright holder for this preprint (which was not certified by peer review) is the author/funder, who has granted medRxiv a license to display the preprint in perpetuity.

All rights reserved. No reuse allowed without permission.

.

171

36. Van Dillen LR, Sahrmann SA, Norton BJ, et al. Reliability of physical examination items used for classification of patients with low back pain. Phys Ther. 1998;78(9):979-988.

37. Harris-Hayes M. Reliability of examiners to classify LBP problems with the Movement System Impairment Classification System. American Association of Orthopedic and Manual Physical Therapy. 2007.

38. Henry SM, Van Dillen LR, Trombley AL, Dee JM, Bunn JY. Reliability of novice raters in using the movement system impairment approach to classify people with low back pain. Man Ther. 2013;18(1):35-40.

39. Trudelle-Jackson E, Sarvaiya-Shah SA, Wang SS. Interrater reliability of a movement impairment-based classification system for lumbar spine syndromes in patients with chronic low back pain. J Orthop Sports Phys Ther. 2008;38(6):371-376.

40. Harris-Hayes M, Van Dillen LR. The inter-tester reliability of physical therapists classifying low back pain problems based on the movement system impairment classification system. PM R. 2009;1(2):117-126.

41. Van Dillen LR, Sahrmann SA, Norton BJ, Caldwell CA, McDonnell MK, Bloom NJ. Movement system impairment-based categories for low back pain: stage 1 validation. $J$ Orthop Sports Phys Ther. 2003;33(3):126-142.

42. Winter DA. Biomechanics and Motor Control of Human Movement. 2 ed. New York: John Wiley \& Sons; 1990.

43. Franklin BA, Whaley MH, Howley ET, et al. Section III: Exercise Prescription. In: Johnson EP, Napora LS, eds. ACSM's Guidelines for Exercise Testing and Prescription. 6th ed. Baltimore, MD: Lippincott Williams \& Wilkins; 2000:137-234.

44. Harris-Hayes M, Holtzman GW, Early J, Van Dillen LR. Development and preliminary reliability testing of an assessment of patient independence in performing a treatment program: standardized scenarios. J Rehabil Med. 2010;42(3):221-227.

45. R Core Team. R: A language and environment for statistical computing. In: R Foundation for Statistical Computing; 2018.

46. Wickham H. ggplot2: Elegant Graphics for Data Analysis. In: Springer-Verlag; 2016.

47. Wickham H, Francois R, Henry L, Muller K. dplyr: A Grammar of Data Manipulation. R package version 0.8.0.1. 2019.

48. Snijders TA, Bosker RJ. Multilevel analysis: An introduction to basic and advanced multilevel modeling. Sage; 2011. 
medRxiv preprint doi: https://doi.org/10.1101/2022.02.28.22271619; this version posted March 2, 2022. The copyright holder for this preprint (which was not certified by peer review) is the author/funder, who has granted medRxiv a license to display the preprint in perpetuity.

$\underline{\text { Tables }}$

Table 1: Mean +/- SD for participant characteristics at baseline by treatment group

\begin{tabular}{lccc}
\hline & $\begin{array}{c}\text { Strength and } \\
\text { Flexibility Exercise } \\
(\mathbf{n}=\mathbf{7 7})\end{array}$ & $\begin{array}{c}\text { Motor Skill } \\
\text { Training } \\
(\mathbf{n}=\mathbf{7 7})\end{array}$ & p value \\
\hline Age (years) & $42.6 \pm 11.7$ & $42.5 \pm 11.8$ & 0.94 \\
Female, no. (\%) & $52(68)$ & $43(56)$ & 0.14 \\
BMI (kg/m²) & $25.4 \pm 3.2$ & $26.1 \pm 3.1$ & 0.18 \\
Duration of LBP (years) & $10.9 \pm 9.3$ & $9.7 \pm 7.9$ & 0.39 \\
LBP Medication Use no. (\%) & $48(62.3)$ & $45(58.4)$ & 0.63 \\
Function (MODQ, 0-100\%) † & $32.7 \pm 10.2$ & $32.5 \pm 9.3$ & 0.90 \\
Average Pain (NRS, 0-10) $\ddagger$ & $4.7 \pm 1.8$ & $4.7 \pm 1.6$ & 0.96 \\
Worst Pain (NRS, 0-10) $¥$ & $6.3 \pm 2.0$ & $6.8 \pm 1.6$ & 0.09 \\
Fear-Work (FABQ-W, 0-42) § & $11.0 \pm 8.3$ & $11.7 \pm 8.9$ & 0.62 \\
Fear-Physical (FABQ-P, 0-24) § & $14.9 \pm 6.1$ & $14.1 \pm 5.1$ & 0.35 \\
SF-36 Physical q & $42.9 \pm 6.8$ & $40.7 \pm 6.9$ & 0.05 \\
SF-36 Mental $\mathbf{~}$ & $48.8 \pm 11.5$ & $52.1 \pm 9.2$ & 0.05 \\
\hline
\end{tabular}

† modified Oswestry Disability Questionnaire scores range between 0\% (no LBP-related functional limitation) and 100\% (max limitation)

$\ddagger$ Patient report of average or worst pain in the prior 7 days on verbal numeric pain rating scale between 0 (no pain) and 10 (pain as bad as can be)

$\S$ Fear-Avoidance Beliefs Questionnaire physical activity subscale score ranges from 0-24 and work subscale score ranges from 0-42 with higher scores indicating higher fear-avoidance 9 36-Item Short Form Health Survey (SF-36) Physical and Mental Component summary scores are scaled and normalized to have a mean of 50 and standard deviation of 10 in the normal 1998 US population 
medRxiv preprint doi: https://doi.org/10.1101/2022.02.28.22271619; this version posted March 2, 2022. The copyright holder for this preprint (which was not certified by peer review) is the author/funder, who has granted medRxiv a license to display the preprint in perpetuity. All rights reserved. No reuse allowed without permission.

Table 2: Results of hierarchical linear modeling analyses of lumbar contribution over time at baseline, post-treatment and 6 month follow up

\begin{tabular}{lccc}
\hline & Baseline & & \\
\hline Fixed effect & Beta coefficient & $C l$ & $p$-value \\
\hline Intercept $\dagger$ & & & \\
TxGroup & -2.385 & $(-7.74,2.97)$ & 0.384 \\
Gender & -5.288 & $(-10.58,0.01)$ & 0.052 \\
Age & -0.224 & $(-0.45,0.01)$ & 0.056 \\
LBP Duration & -0.187 & $(-0.49,0.12)$ & 0.241 \\
Linear ¥, §, ๆ & & & \\
TxGroup & -2.012 & $(-2.55,-1.48)$ & $<0.001$ \\
Gender & 0.056 & $(-0.11,0.23)$ & 0.511 \\
Age & -0.004 & $(-0.01,0.01)$ & 0.261 \\
LBP Duration & 0.004 & $(-0.01,0.02)$ & 0.391 \\
Baseline LC & -0.013 & $(-0.03,0.01)$ & 0.197 \\
TxGroup X Gender & -0.177 & $(-0.41,0.06)$ & 0.157 \\
TxGroup X Age & 0.015 & $(0.01,0.02)$ & 0.003 \\
TxGroup X LBP Duration & -0.010 & $(-0.02,0.01)$ & 0.155 \\
TxGroup X Baseline LC & -0.058 & $(-0.08,-0.03)$ & $<0.001$ \\
Quadratic §, ף, ¥ & & & \\
TxGroup & 0.049 & $(0.04,0.06)$ & $<0.001$ \\
Baseline LC & 0.001 & $(-0.01,0.01)$ & 0.302 \\
TxGroup X Baseline LC & 0.002 & $(0.00,0.02)$ & $<0.001$ \\
\hline
\end{tabular}

Post-Treatment

\begin{tabular}{lccc}
\hline Fixed effect & Beta coefficient & Cl & $p$-value \\
\hline Intercept $†$ & & & \\
TxGroup & -16.154 & $(-19.54,-12.76)$ & $<0.001$ \\
Gender & -4.973 & $(-8.52,-1.42)$ & 0.036 \\
Age & -0.061 & $(-0.22,0.09)$ & 0.188 \\
LBP Duration & -0.129 & $(-0.34,0.08)$ & 0.382 \\
Linear ¥, §, 9 & & & \\
TxGroup & -1.112 & $(-1.43,-0.79)$ & $<0.001$ \\
Gender & -0.045 & $(-0.24,0.15)$ & 0.655 \\
Age & -0.007 & $(-0.02,0.01)$ & 0.093 \\
LBP Duration & 0.001 & $(-0.01,0.01)$ & 0.881 \\
Baseline LC & -0.060 & $(-0.07,-0.05)$ & $<0.001$ \\
TxGroup X Gender & -0.161 & $(-0.43,0.11)$ & 0.241 \\
TxGroup X Age & 0.014 & $(0.00,0.03)$ & 0.017 \\
TxGroup X LBP Duration & -0.007 & $(-0.02,0.01)$ & 0.393 \\
TxGroup X LC & -0.014 & $(-0.03,0.00)$ & 0.023 \\
Quadratic §, ๆ, ¥ & & & \\
TxGroup & 0.047 & $(0.04,0.06)$ & $<0.001$ \\
Baseline LC & 0.002 & $(0.00,0.01)$ & $<0.001$ \\
TxGroup X Baseline LC & 0.001 & $(0.00,0.01)$ & 0.013 \\
\hline
\end{tabular}




\section{6-month follow up}

\begin{tabular}{|c|c|c|c|}
\hline Fixed effect & Beta coefficient & SE & $p$-value \\
\hline \multicolumn{4}{|l|}{ Intercept † } \\
\hline TxGroup & -17.961 & $(-23.12,-12.80)$ & $<0.001$ \\
\hline Gender & -6.281 & $(-11.74,-0.82)$ & 0.026 \\
\hline Age & -0.056 & $(-0.28,0.17)$ & 0.613 \\
\hline LBP Duration & -0.145 & $(-0.46,0.17)$ & 0.364 \\
\hline \multicolumn{4}{|l|}{ Linear $\ddagger, \S, \emptyset$} \\
\hline TxGroup & 1.470 & $(1.05,1.89)$ & $<0.001$ \\
\hline Gender & -0.088 & $(-0.27,0.09)$ & 0.341 \\
\hline Age & -0.003 & $(-0.01,0.01)$ & 0.475 \\
\hline LBP Duration & -0.001 & $(-0.01,0.01)$ & 0.939 \\
\hline Baseline LC & -0.005 & $(-0.02,0.01)$ & 0.567 \\
\hline TxGroup X Gender & 0.103 & $(-0.06,0.27)$ & 0.222 \\
\hline TxGroup X Age & -0.002 & $(-0.01,0.01)$ & 0.635 \\
\hline TxGroup X LBP Duration & -0.002 & $(-0.01,0.01)$ & 0.695 \\
\hline TxGroup X Baseline LC & 0.048 & $(0.02,0.07)$ & $<0.001$ \\
\hline \multicolumn{4}{|l|}{ Quadratic $\S, \emptyset, ¥$} \\
\hline TxGroup & 0.052 & $(0.04,0.06)$ & $<0.001$ \\
\hline Baseline LC & 0.001 & $(-0.01,0.01)$ & 0.198 \\
\hline TxGroup X Baseline LC & 0.002 & $(0.00,0.01)$ & 0.011 \\
\hline
\end{tabular}

TxGroup represents the difference in lumbar contribution (LC) between strength and flexibility exercise and motor skill training.

† Gender, Age and LBP Duration are differences in the grand means, irrespective of TxGroup

¥ Linear slope at the centered time point

$\S$ Main effects are within strength and flexibility exercise

I Interaction effects represent the difference between strength and flexibility exercise and motor skill training.

$¥$ Quadratic component at the centered time point 
medRxiv preprint doi: https://doi.org/10.1101/2022.02.28.22271619; this version posted March 2, 2022. The copyright holder for this preprint (which was not certified by peer review) is the author/funder, who has granted medRxiv a license to display the preprint in perpetuity. All rights reserved. No reuse allowed without permission.

$497 \quad$ Figure Legends

498 Figure 1. Predicted values based on hierarchical linear modeling analysis of lumbar contribution

499 (LC) for motor skill training (MST) and strength and flexibility exercise (SFE). Confidence intervals 500 are displayed at the three centering locations of baseline, post-treatment and 6 months post501 treatment. Person-specific moderating effects are displayed for 1A. Gender, 1B. Age, 1C.

502 Duration of LBP and 1D. Baseline lumbar contribution (LC_base). 
medRxiv preprint doi: https://doi.org/10.1101/2022.02.28.22271619; this version posted March 2, 2022. The copyright holder for this preprint (which was not certified by peer review) is the author/funder, who has granted medRxiv a license to display the preprint in perpetuity.
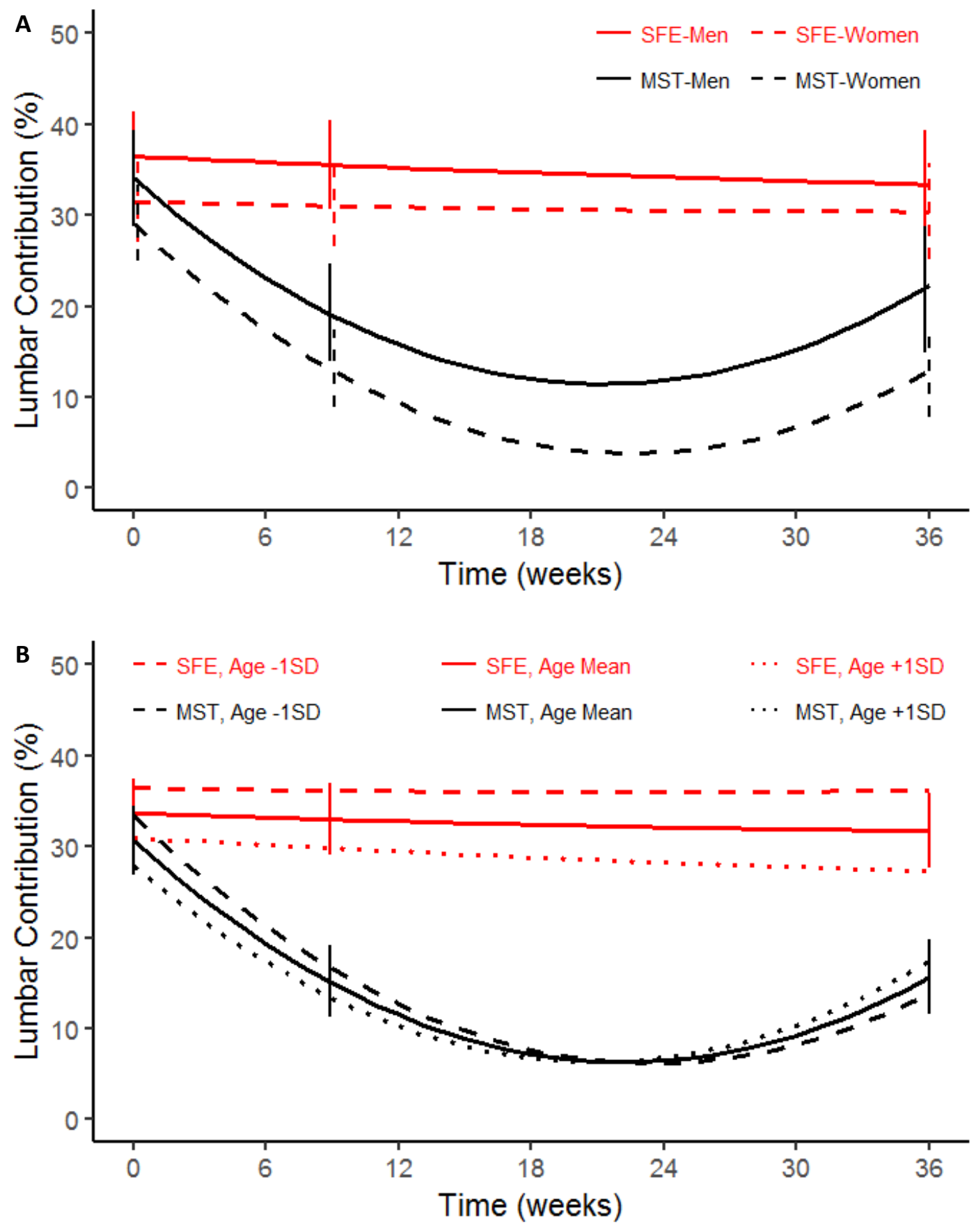
medRxiv preprint doi: https://doi.org/10.1101/2022.02.28.22271619; this version posted March 2, 2022. The copyright holder for this preprint (which was not certified by peer review) is the author/funder, who has granted medRxiv a license to display the preprint in perpetuity. All rights reserved. No reuse allowed without permission.
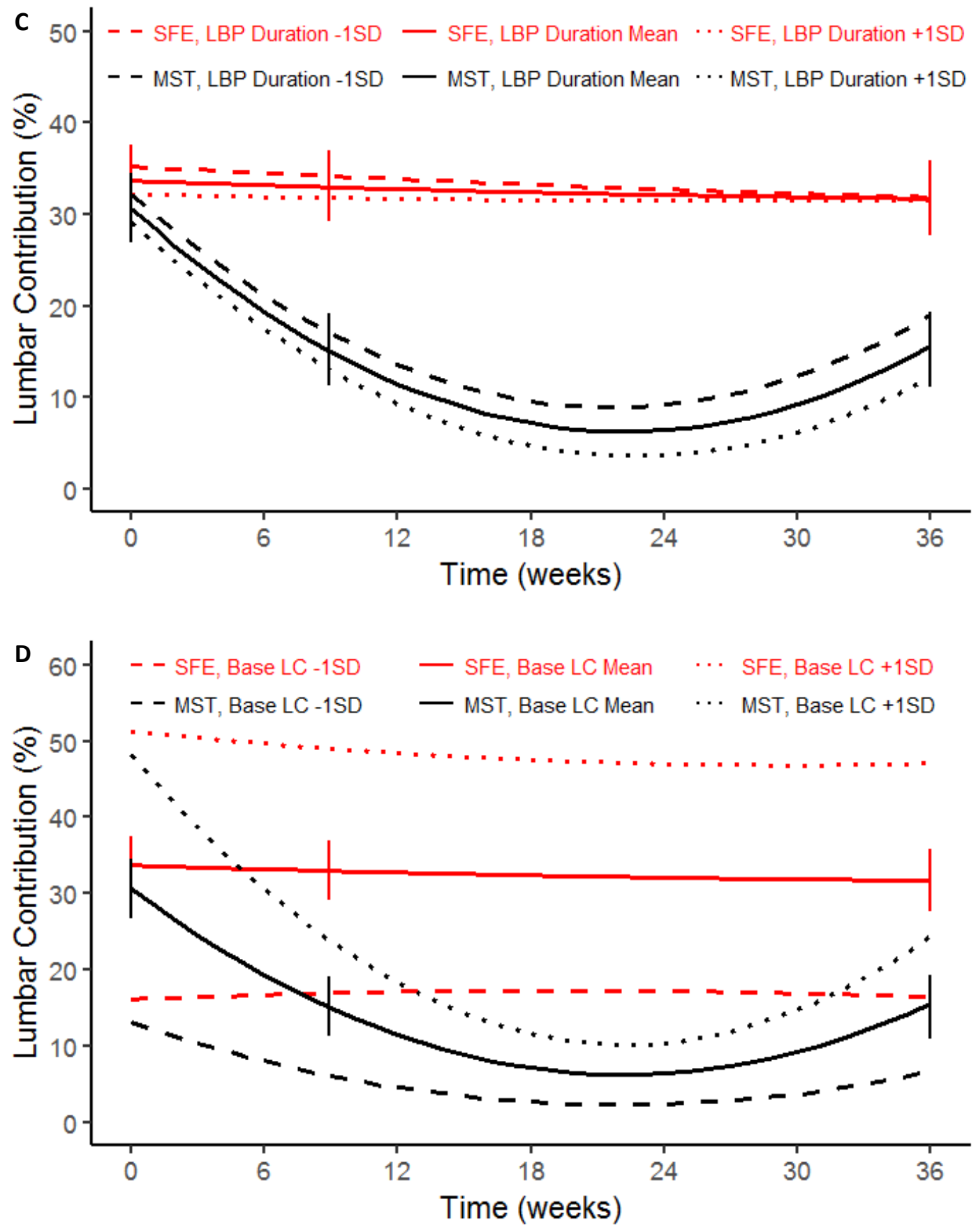